\title{
Characteristics of cows' cicatricial metabolism of different linearity
}

\author{
E. V. Razhina ${ }^{1 凶}$ \\ ${ }^{1}$ Ural State Agrarian University, Ekaterinburg, Russia \\ ¿-mail:eva.mats@mail.ru
}

\begin{abstract}
The aim of this work is to investigate the relationship between indicators of cicatricial digestion and linearity of cows. Methods. The research was carried out in the breeding enterprises of the Sverdlovsk region on the livestock of Ural-type cows. Cicatricial fluid was collected with an oropharyngeal rubber probe, and a wooden yaw was also used. Cicatricial content was assessed at the Chelyabinsk Interregional Veterinary Laboratory. The $\mathrm{pH}$ value was determined by the electrometric method, VFA - in the Markgam apparatus, ammonia - by the microdiffusion method. Ciliates - in Goryaev's chamber and under a microscope, bacteria - under a microscope with the addition of sodium chloride solution. Statistical data processing was carried out in the Microsoft Office Excel 2010 program. Results. In terms of the number of ciliates and bacteria in the rumen fluid, the Montwick Chieftain cows, characterized by high productive qualities, had an advantage. In terms of $\mathrm{pH}$ and VFA, the Vis Back Ideal line was the best. There were no significant differences between the groups in terms of the amount of ammonia in the rumen. The best animals from the point of view of influence on cicatricial metabolism were the animals of the Vis Back Ideal and Montwick Chieftain lineage. Scientific novelty. Studies have shown that linearity is associated with cicatricial digestion in cows. The relationship of bull lines with indicators of cicatricial metabolism of cows has been determined for the first time. The food in the rumen is digested due to the action of bacteria, ciliates, and fungi. An environment has been created in the rumen for the active development of microflora. Bacteria are able to synthesize amino acids and vitamins. The proventriculus can contain up to 50 species of ciliates.
\end{abstract}

Keywords: bull line, cows, cicatricial metabolism, bacteria and ciliates, volatile fatty acids.

For citation: Razhina E. V. Characteristics of cows' cicatricial metabolism of different linearity // Agrarian Bulletin of the Urals. 2021. No. 10 (213). Pp. 75-80. DOI: 10.32417/1997-4868-2021-213-10-75-80.

Date of paper submission: 27.08.2021, date of review: 03.09.2021, date of acceptance: 15.09.2021.

\section{Introduction}

The health status of cattle, the level of milk production may depend on the function of the rumen and the vital activity of microorganisms. The functioning of the mammary gland is interconnected with the scar. During cicatricial digestion, milk precursors are formed in animals. The rumen occupies about $80 \%$ of the complex stomach volume and plays an important role in the digestion of ruminants. Begins to function a little after birth. It digests up to $70 \%$ of the dry matter of the diet without the participation of digestive enzymes [1, p. 118]. The cattle rumen capacity is $100-300$ liters. The rumen contains 2 sacs - dorsal and ventral, between which the right and left longitudinal grooves run laterally. From the side of the mucous membrane, the grooves correspond to the strands framing the intra-cicatricial opening [16, p. 63].

The mucous membrane of the rumen is lined with squamous keratinized epithelium and contains a variety of papillae up to $1 \mathrm{~cm}$ long [19, p. 12].

The papillae contain a large number of blood and lymph vessels and have the ability to contract. The muscle plate has separate bundles that lie at the base of the papillae. The structure of the muscular membrane has smooth muscle tissue and a small amount of striated muscle tissue [16, p. 65].

The main function of the rumen - the digestion of feed fiber, is performed using the cellulolytic activity of microorganisms [2, p. 214].

Grinding of the feed is performed as a result of repeated chewing, in which the feed is regurgitated from the rumen into the oral cavity, then it is chewed, mixed with saliva and swallowed again. Saliva does not contain digesting enzymes, it helps to moisturize the feed and normalize the acidity of the rumen [19, p.12]. Digestion in the proventriculus occurs with the use of plant cell enzymes, saliva and biological agents [18, p. 141]. For the normalization of cicatricial digestion, it is necessary that the number of feed particles with a size of at least $4 \mathrm{~cm}$ was within $20 \%$ of the dry matter mass of the diet [17, p. 144].

Due to the constant supply of the substrate for bacteria with food, the implementation of absorption through the wall of the rumen into the blood of the products of their vital activity, constant conditions are observed in the rumen [1, p. 118]. 
The main process of cows' digestion is carried out in the rumen under the influence of different types of microflora. The vital activity of microflora is determined by a set of feeds and their quality indicators. In the digestion of feed protein, the leading role is played by bacteria and ciliates contained in the rumen. They help break down more than $40 \%$ of crude protein. The proteins in the feed are degraded to amino acids and ammonia and other metabolites are formed. Microorganisms use ammonia to synthesize their own protein. Protein synthesis can be carried out by microorganisms using urea, ammonium compounds. With increasing productivity, cows are less satisfied in amino acids under the influence of microbial synthesis. The microbial mass can accumulate and die off, enter the abomasum and intestines and be digested. Microbial protein provides a large proportion of the protein requirement of cattle [1, p. 118]. With an excess of protein in the rumen, an increased amount of ammonia is released, entering the bloodstream and causing toxicosis, ketosis or liver dystrophy [11, p. 70]. Individual types of bacteria can have different forms of relationships, which affects the formation of the microbial ecosystem of the proventriculus. The development of both microflora and microfauna in the rumen is facilitated by maintaining a constant temperature within $39-40{ }^{\circ} \mathrm{C}[6, \mathrm{p} .279]$.

Rumen bacteria differ in shape, habitat, end product of vital activity, substrate that is used for nutrition [9, p. 26]. The development and reproduction of some microorganisms can be accompanied by autolysis and the death of others. The rumen contains both live and dead bacteria. In the proventriculus there are streptococci, cocci, cellulolytic, lactic acid microorganisms that enter the rumen with water and food. The main bacteria - cellulolytic, promote the breakdown and digestion of fiber [19, p. 12]. Amylolytic microorganisms feed on starch and maltose, further breaking them down to succinic, acetic acids. Lipolytic - break down fat to form glycerol and fatty acids. Lactic acid bacteria form lactic acid by breaking down starch and sugar. Bacteria also include clostridia, ureolytic bacteria, bacteroids [9, p. 26]. For the development of bacteria, the intake of starch, carbohydrates (disaccharides), minerals and vitamins is necessary. The total bacterial mass of the rumen of cattle is from 4 to $7 \mathrm{~kg}$ [6, p. 280].

The microflora of the gastrointestinal tract is responsible for the synthesis of vitamins $\mathrm{B}$ and $\mathrm{K}$, glycogen, microbial lipids. Some bacteria, for example pigment bacteria, synthesize carotene. The microflora of the gastrointestinal tract creates antibiotics that suppress the development of pathogenic microorganisms. Microorganisms play an important role in the digestion of fiber and protein nutrition. When analyzing the nutritional value of protein in the diets of cows, degradable and non-degradable protein are considered. High consumption of breakdown protein can cause excessive accumulation of ammonia, which is converted to urea in the liver. Approximately $35-45 \%$ of proteins contained in the diet should be in the indigestible form [3, p. 34].
According to the authors, highly productive animals have a special cicatricial microflora, amylolytic bacteroids are formed, leading to a decrease in $\mathrm{pH}$. The growth of lactutilizing bacteria is inhibited. These conditions are most optimal for lactobacilli that produce lactic acid. The content of most microorganisms in the rumen changes during the day, which is associated with the processes of fermentation of the rumen, the formation of VFA and other components [10, p. 38].

The contents of the rumen contain from 200 to 1200 thousand $/ \mathrm{ml}$ ciliates. The most widespread are representatives of the Spirotricha subclass. In the presence of a large number of ciliates in the rumen, enzymatic processes normally proceed. Large ciliates are highly sensitive to environmental changes, which first of all disappear under unfavorable conditions [11, p. 71]. They can function actively in a neutral or slightly alkaline environment. They have the ability to absorb starch grains from the liquid of the gastric contents [9, p. 26].

Ciliates absorb the non-protein nitrogen of the feed and convert it to the protein nitrogen of their own body, making it available for the digestion of ruminants. The duration of the breakdown of the starch is longer. VFAs created by ciliates have a high degree of bioavailability [9, p. 27].

Ciliates grind and loosen food, digest proteins, sugars, starch, synthesize amino acids [3, p. 30]. By the nature of nutrition, ciliates are divided into 3 types: herbivorous, starch-eating and carnivorous [9, p. 27].

When fasting for 3-4 days, ciliates almost completely disappear from the scar fluid. The use of starch, fiber, sugar, vegetable protein forms an environment in the rumen that has a beneficial effect on protozoa. Infusoria colonization of the proventriculus is carried out gradually [7, p. 169].

The proteins of ciliates are the most complete in comparison with the proteins of bacteria.

The rumen fluid may contain fungi (yeast, mold, etc.). They carry out the fermentation of sugars, the synthesis of amino acids, B vitamins, glycogen [9, p. 27].

The main factors influencing the cicatricial digestion of cows are the lack or excess of energy and protein nutrition. Lack of energy supply leads to low activity of the rumen microflora, it is difficult to assimilate the nutrient elements of the feed. An excess of energy supply leads to obesity and cardiovascular diseases [11, p. 72].

From the carbohydrates contained in the rumen, VFA - volatile fatty acids are formed, the main of which are acetic (55-70\%), propionic (15-20\%), butyric (10$15 \%$ ). The normal course of the process of cicatricial digestion is assessed by a certain amount of VFA. The total content of VFA in the rumen can be determined by the composition and quality of the feed, the level of fiber and starch. VFA synthesis decreases in diseases of the proventriculus [11, p. 71]. Individual acids are absorbed in the rumen at different rates, which are determined by the acid concentration and the $\mathrm{pH}$ reaction $[1, \mathrm{p} .120]$. The main source of milk fat are acetic and butyric acids, glucosepropionic acid. The increase in the content of propionic 
Agrarian Bulletin of the Urals No. 10 (213), 2021

acid in the rumen helps to improve the use of nitrogen, increases the amount of protein in milk. A decrease in the concentration of propionic acid leads to a decrease in liver glycogen and blood sugar [8, p. 396]. An increased amount of acetic and butyric acids in the rumen leads to ketosis [11, p. 71]. The body consumes acetic acid as a source of energy. According to the authors, butyric acid, in comparison with acetic acid, has a more effective effect on the scar. Butyric acid takes part in the synthesis of fatty acids by forming ketone bodies $[14$, p. 25]. The general increase in the content of volatile fatty acids in the rumen contributes to an increase in the milk production of cows [7, p. 169].

An intermediate product of the conversion of carbohydrates in the rumen is lactic acid. The content of lactic acid increases with the use of animal feed, which is distinguished by a significant amount of starch (cereal grain, root crops, tubers). With a high intake of lactic acid, the acid-base balance of the rumen shifts to the acidic side, possibly the occurrence of lactic acidosis [11, p. 72].

When animals consume a large amount of feed saturated with carbohydrates, the $\mathrm{pH}$ drops below 6 . When the $\mathrm{pH}$ drops to $4-5$, digestive upset may occur, and the content of ciliates in the rumen decreases. When cows eat large quantities of legumes, the $\mathrm{pH}$ will shift above 7.3. An alkaline reaction contributes to the suppression of the function of ciliates, the consequence is their death. Then putrefactive microflora develops, the ammonia content increases. The accumulation of ammonia characterizes the level of nitrogen consumption by the body of animals. Ammonia is absorbed into the bloodstream and can cause liver intoxication and degeneration. The level of ammonia can be influenced by the degree of fermentation reactions in the rumen, the consumption of ammonia by microorganisms and the degree of absorption into the blood [11, p.71].

The increased total acidity of the contents of the rumen can be determined by the intensity of fermentation processes, the formation of acidic metabolites, represented by volatile fatty acids [1, p. 120].

Adequate feeding and quality of feed is a guarantee of animal health [4, p. 27]. With proper feeding, cicatricial metabolism improves and, consequently, the indicators of milk production of cows increase.

Basically, different researchers have considered the effect of types of feed and various feed additives on the intensity of the processes in the rumen. In addition to the usefulness and quality of feed, genetic factors, for example, a bull's line, can influence the indicators of cicatricial digestion, which has not been studied by other authors.

Breeding along lines is one of the main methods for improving the indicators of milk productivity of cows [5, p. 4164].

The components of milk productivity are more dependent on the course of physiological processes, digestion plays a significant role [12, p. 2107].

With the skillful use of breeding along the lines, it is possible to eliminate certain disadvantages [15, p. 242]. The number of lines in the breed, the qualitative composi- tion characterize the genetic diversity of the broodstock of a herd of cattle [16, p. 167].

The aim of this work is to investigate the relationship between indicators of cicatricial digestion and linearity of cows.

Methods
The study was carried out on the livestock of Holsteinized black-and-white Ural type cows in 2 breeding enterprises of the Sverdlovsk region.

For the tests, animals were preliminarily formed into groups (10 animals each), taking into account the physiological state, lactation, live weight, linearity (Reflection Sovering 198998, Vis Back Ideal 1013415, Montwick Chieftain 95679).

The animals were fed in accordance with the accepted diets of the breeding enterprises, taking into account the feeding norms of cattle. All cows during the study were in the same conditions of feeding and housing. Feeding is two times a day. The system of keeping the stall, the method - tethered.

For sampling the contents of the rumen, an oropharyngeal probe, which was a rubber tube, was used. A wooden yawner was used for sounding. The end of the probe was inserted into the root of the tongue and pushed forward, causing swallowing. The contents of the scar flowed out by gravity. Samples were filtered and preserved with $10 \%$ formalin solution. The components of the cicatricial content were assessed in an accredited interregional veterinary laboratory in Chelyabinsk.

The $\mathrm{pH}$ was assessed by the electrometric method, VFA - in the Markgam apparatus, ammonia - by the microdiffusion method. Ciliates were identified in a Goryaev chamber and under a microscope. The bacteria were counted under a microscope with the addition of sodium chloride solution.

The digital material was processed using the methods of variation statistics using Microsoft Excel.

\section{Results}

There was made a comparative analysis of the bacteria and ciliates contained in the rumen of cows of different linearity (Fig. 1, 2).

In terms of the content of bacteria in the rumen, the best were animals of the Montwick Chieftain lineage $11.3 \pm 0.1$ billion/ml, which surpassed the Vis Back Ideal cows by $5.3 \%(P<0.05)$, the Reflection Sovering line by $3.5 \%$.

In terms of the number of ciliates in the cicatricial content, the Montwick Chieftain cows had an advantage $639.1 \pm 14.1 \mathrm{billion} / \mathrm{ml}$, having a significant superiority over the Vis Back Ideal animals $-11.7 \%$ at $P<0.05$. The value of this indicator for cows of the Reflection Sovering line took an intermediate position with an insignificant intergroup difference.

An increase in the content of bacteria and ciliates in the rumen of Montwick Chieftain cows may indicate a better course of digestive processes, which is confirmed by rather high indicators of milk productivity (milk yield in 305 days of lactation was $6708 \mathrm{~kg}$, protein content $3.12 \mathrm{~kg}$ ). And the productivity of cattle can be determined 
by the availability of exchangeable protein, which is decrease to 5; with the predominance of roughage in the formed by the entry of microbial protein into the intestine. The intake of protein in the body of cows is carried out not only with feed, but also due to the microbial protein of the rumen.

Intergroup differences in $\mathrm{pH}$, ammonia, volatile fatty acids are presented in the table 1 .

The hydrogen index is interrelated with the intensity of carbohydrate metabolism and is determined by the composition of the diet, acid balance in the body. Healthy cows have a $\mathrm{pH}$ between 6.2 and 7.2. With a concentrate type of feeding, the reaction of the cicatricial content can

diet, the $\mathrm{pH}$ rises (more than 7.5) [13, p. 400].

The $\mathrm{pH}$ value of the rumen is determined by the balance between fermentation acids, their absorption and neutralization [9, p. 60].

The $\mathrm{pH}$ value was 6.4-6.8. A lower $\mathrm{pH}$ value of $-6.4 \pm 0.03$ was found in the cicatricial contents of Vis Back Ideal cows, which is $5.9 \%$ lower $(P<0.05)$ compared to Reflection Sovering animals. A pH value of 6.4 indicates a more acidic valence in the rumen fluid and can be determined by an increase in volatile fatty acids in the rumen.

\section{Bacterial content, billion/ml}

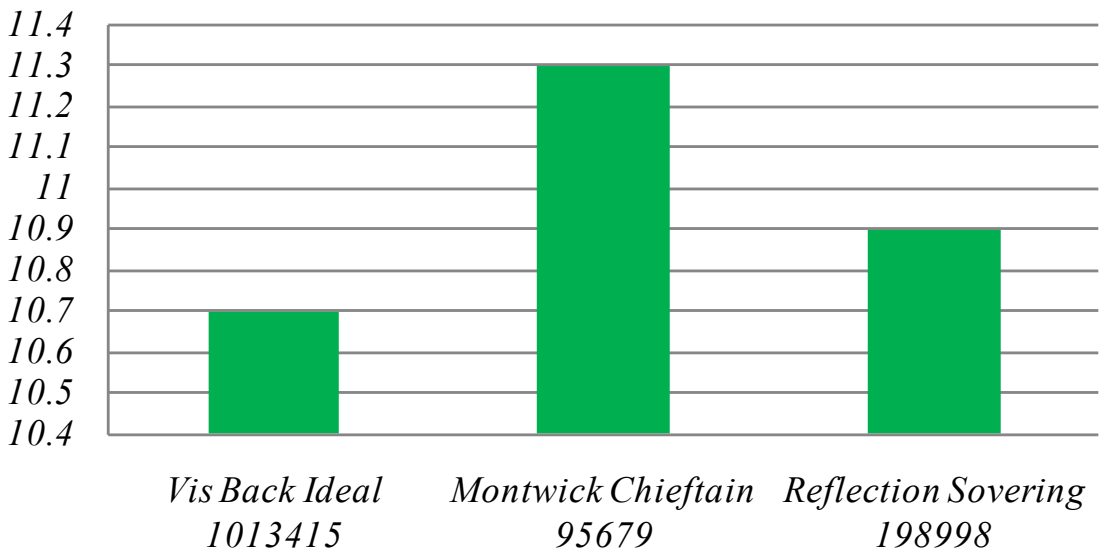

Fig. 1. The number of bacteria in the scar fluid of cows of three lines

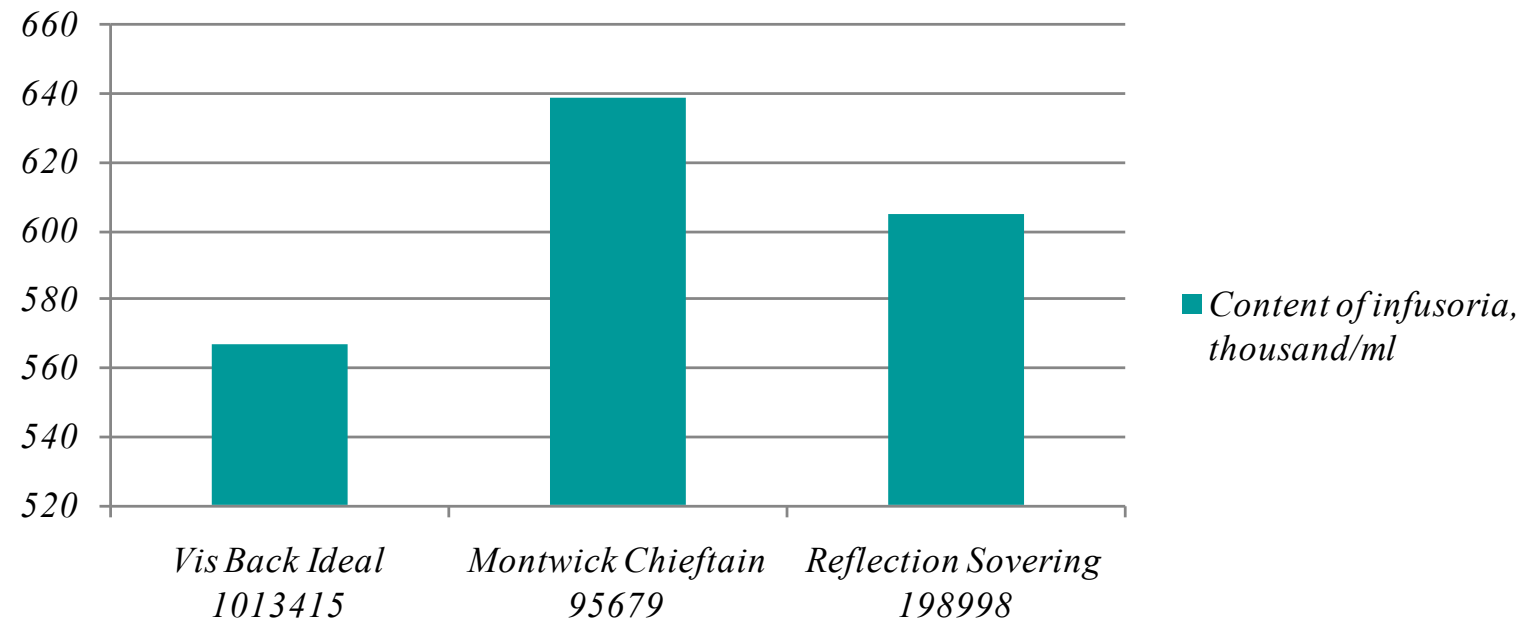

Fig. 2. The content of infusoria in the scar fluid of cows of different lines

Table 1

Indicators of scar digestion of cows of different lines

\begin{tabular}{|c|c|c|c|}
\hline \multirow[b]{2}{*}{ Indicator } & \multicolumn{3}{|c|}{ Linear affiliation } \\
\hline & $\begin{array}{c}\text { Vis Back Ideal 1013415, } \\
n=10\end{array}$ & $\begin{array}{l}\text { Montwick Chieftain 95679, } \\
n=10\end{array}$ & $\begin{array}{c}\text { Reflection Sovering 198998, } \\
n=10\end{array}$ \\
\hline pH value & $6.4 \pm 0.03$ & $6.7 \pm 0.04$ & $6.8 \pm 0.02 *$ \\
\hline $\begin{array}{l}\text { Ammonia content, } \\
m g \%\end{array}$ & $10.1 \pm 0,03$ & $10.3 \pm 0.1$ & $10.3 \pm 0.02$ \\
\hline $\begin{array}{l}\text { Content of volatile } \\
\text { fatty acids, mmol/l }\end{array}$ & $97.0 \pm 1.2 *$ & $91.4 \pm 1.0$ & $91.0 \pm 1.4$ \\
\hline
\end{tabular}




\section{Agrarian Bulletin of the Urals No. 10 (213), 2021}

Part of the protein that feeds cows is broken down to form amino acids and ammonia. The ammonia content in the rumen of the experimental animals was in the range of $10.1-10.3 \mathrm{mg} \%$, the difference between the groups was insignificant.

Carbohydrate metabolism of animals is determined by the amount of volatile fatty acids, the ratio of which is determined by the amount of nutrients, which are a favorable environment for the development of microorganisms. Cows of the Vis Back Ideal line had an advantage in the content of VFA - $97.0 \pm 1.2 \mathrm{mmol} / \mathrm{l}$, which significantly exceeded the peers of the Reflection Sovering line by $6.2 \%(P<0.05)$. An intermediate position in terms of the VFA content in the rumen $-91.4 \pm 1.0 \mathrm{mmol} / \mathrm{l}$ was found in the animals of the Montwick Chieftain line. The best indicator of VFA in the rumen fluid of cows of the Vis Back Ideal lineage can be associated with a high yield of milk fat and protein in the milk of cows of this group.

\section{Discussion and Conclusion}

The best indicators of cicatricial metabolism were observed in animals of the Vis Back Ideal 1013415 and Montwick Chieftain 95679 lines. The cicatricial contents of the Montwick Chieftain animals contained a higher number of bacteria and ciliates, affecting the improvement of digestion and activation of enzymatic processes that convert feed protein into protein of microbial ori- gin, regulating synthesis milk proteins by the mammary gland. When analyzing the indicators of milk productivity of cows, carried out in previous studies, it was the animals of the Montwick Chieftain line that had the advantage in terms of the protein content in milk.

The Vis Back Ideal cows were the best in terms of the content of volatile fatty acids, ammonia and $\mathrm{pH}$ of the reaction of the environment. VFAs affect the formation of milk fat (acetic acid) and protein (propionic acid). The highest yield of milk fat and protein in milk was found in animals of the Vis Back Ideal lineage. Protein digested in the rumen is broken down into amino acids and ammonia. The acidity in the rumen can be controlled with the correct ratio of nitrogen sources. Due to the production of acetate and butyrate, the production of milk fat by animals is increased. The highest yield of milk fat is found in the milk of cows of the Vis Back Ideal line.

The advantages of Vis Back Ideal and Montwick Chieftain animal lines in terms of cicatricial digestion may also be related to the correct functioning of the rumen.

Thus, the cows of each line had different components of cicatricial digestion. Cicatricial metabolism is interrelated with indicators of milk production of cows. Animals of all three lines of bulls have different milk yields, butterfat and protein milk yields, milk fat and protein yields.

\section{References}

1. Bogolyubova N. V., Zaytsev V. V., Shalamova S. A. Sposob regulyatsii rubtsovogo pishchevareniya u molochnykh korov [Methods of dairy cows rumen digestion regulation] // Jounal of NIIMZH. 2019. No. 4 (36). Pp. 118-122. (In Russian.)

2. Bogolyubova N. V., Zaytsev V. V., Shalamova S. A., Gizatullin O. Sh., Seitov M. S. Regulyatsiya rubtsovogo pishchevareniya u molochnулh korov // Izvestiya Orenburg State Agrarian University. 2019. No. 6 (80). Pp. $214-216$. (In Russian.)

3. Vafin I. T. Vliyanie na organizm vysokoproduktivnykh korov i kachestvo moloka mineral'no-probioticheskikh kontsentratov napravlennogo deystviya: dis. ... kand. biol. nauk: 06.02 .05 [Effects on the body of highly productive cows and the quality of milk of mineral-probiotic concentrates directed action: dis. ... candidate of biological sciences: 06.02.05]. Kazan, 2020. 125 p. (In Russian.)

4. Gorelik O. V., Dolmatova I. A., Gorelik A. S., Gorelik V. S. The effectiveness of dietary supplements Ferrourtikavit usage for the dairy cows // Advances in Agricultural and Biological Sciences. 2016. Vol. 2. No. 2. Pp. $27-33$.

5. Donnik I. M., Loretts O. G., Shkuratova I. A., Isaeva A. G., Krivonogova A. S. Genetic formation factors of dairy efficiency and quality of cattle milk // Indo American Journal of Pharmaceutical Sciences. 2017. Vol. 4. No. 11. Pp. 4163-4169.

6. Ivanov A. A., Voynova O. A., Ksenofontov D. A., Polyakova E. P. Sravnitel'naya fiziologiya zhivotnykh: uchebnik [Comparative animal physiology: textbook]. 2nd ed., revised. Saint Petersburg: Izdatel'skiy dom "Lan”, 2021. 416 p. (In Russian.)

7. Kalyuzhnyy I. I., Ubiraev S. P., Shcherbakov G. G., Yashin A. V., Gertman A. M., Elenschleger A. A., Rykhlov A. S. Kliniko-biohimicheskie aspekty kislotno-osnovnogo gomeostaza i ih znachenie v patologii produktivnyh zhivotnyh: monografiya [Clinical and biochemical aspects of acid-base homeostasis and their significance in the pathology of productive animals: monograph]. Saint Petersburg: Izdatel'skiy dom “Lan”, 2019. 191 p. (In Russian.)

8. Kalyuzhnyy I. I., Shcherbakov G. G., Yashin A. V., Barinov N. D., Derezina T. N. Klinicheskaya gastroenterologiya zhivotnykh: uchebnik [Clinical gastroenterology of animals: textbook]. $2^{\text {nd }}$ ed., revised. Saint Petersburg: Izdatel'skiy dom “Lan", 2021. 448 p. (In Russian.)

9. Kosolapov A. V. Effektivnost' ispol'zovaniya polisakharidov v kormlenii vysokoproduktivnykh korov; dis. ... kand. s.-kh. nauk: 06.02.08 [The effectiveness of the use of polysaccharides in the feeding of highly productive cows: dis. ...candidate of agricultural sciences: 06.02.08]. Moscow, 2017. 130 p. (In Russian.)

10. Laptev G., Il'ina L., Soldatova V. Mikrobiom rubtsa zhvachnykh: sovremennye predstavleniya [Microbiome of ruminants' rumen: modern concepts] // Dairy cattle breeding. 2018. No. 10. Pp. 38-41. (In Russian.) 
11. Lobkov V. Yu., Frolov A. I. Tehnologiya vyrashchivaniya krupnogo rogatogo skota: monografiya [Technology of cattle breeding: monograph]. Yaroslavl: Izd-vo Yaroslavskaya GSKhA. 2016. 182 p. (In Russian.)

12. Mikolaychik I. N., Morozova L. A., Chumakov V. G., Abileva G. U., Loretts O. G., Bykova O. A. Productive indicators and physiological and biochemical status of dairy cows received biotechnological additives // Research Journal of Pharmaceutical, Biological and Chemical Sciences. 2019. Vol. 10. No. 1. Pp. 2106-2116.

13. Nevedomskiy V. V., Agafonova E. G., Osokin N. A., Skvortsova N. I. Otsenka rubtsovogo pishchevareniya u korov [Assessment of scar digestion in cows] // Sovremennye problemy i perspektivy razvitiya agropromyshlennogo kompleksa: sbornik statey po itogam mezhdunarodnoy nauchno-prakticheskoy konferentsii. Saratov, 2019. Pp. 399-403. (In Russian.)

14. Razumovskiy N., Smunev V. Stanovlenie rubtsovogo pishchevareniya. Uskorennoe razvitie rubtsa: pol'za ili vred? [Formation of cicatricial digestion. Accelerated scar development: benefit or harm?] // Animal Husbandry of Russia. 2018. No. 2. Pp. 25-27. (In Russian.)

15. Randelin A. V., Kaidulina A. A., Barmina T. N., Surkova S. A. Molochnaya produktivnost' korov datskoy selektsii raznoy lineynoy prinadlezhnosti [Dairy productivity of Danish-bred cows of different linear affiliation] // Proceedings of the Nizhnevolzhsky agrouniversitetskiy complex: science and higher professional education. 2018. No. 2 (50). Pp. 207-212. (In Russian.)

16. Rasputina O. V., Vlasov A. P. Sistema organov pishchevareniya: uchebnik [Digestive system: textbook]. Novosibirsk: ITs NGAU “Zolotoy Kolos”, 2019. 118 p. (In Russian.)

17. Rodionov G. V., Tabakova L. P., Ostroukhova V. I. Tehnologiya proizvodstva moloka: uchebnik dlya vuzov [ production technology: textbook for universities]. Saint Petersburg: Izdatel'skiy dom "Lan”, 2021. 236 p. (In Russian.)

18. Savinkov A. V., Meshkov V. M. Patologicheskaya fiziologiya: uchebnik [Pathological physiology: textbook]. Kinel: RIO SGSHA, 2018. 188 p. (In Russian.)

19. Temiraev V. Kh., Temiraev R. B., Kokaeva M. G., Baeva Z. T., Kalabekov A. L. Potrebitel'skie kachestva moloka i molochnykh produktov, osobennosti obmena veshchestv korov pri skarmlivanii antioksidantov i adsorbentov: monografiya [Consumer qualities of milk and dairy products, peculiarities of cows' metabolism when feeding antioxidants and adsorbents: monograph]. Vladikavkaz: Izdatel'skiy dom Gorskogo GAU, 2018. 176 p. (In Russian.)

20. Filinskaya O. V., Zhukina D. M. Molochnaya produktivnost' korov yaroslavskoy porody v zavisimosti ot lineynoy prinadlezhnosti [Dairy productivity of Yaroslavl breed cows depending on the linearity] // Povyshenie urovnya i kachestva biogennogo potentsiala $\mathrm{v}$ zhivotnovodstve: sbornik nauchnykh trudov po materialam IV mezhdunarodnoy nauchno-prakticheskoy konferentsii. Yaroslavl, 2018. Pp. 166-170. (In Russian.)

\section{Authors'information:}

Eva V. Razhina', senior lecturer of the department of biotechnology and food products, ORCID 0000-0002-6305-1783,AuthorID 675731; +7982 739-63-51,eva.mats@mail.ru

${ }^{1}$ Ural State Agrarian University, Ekaterinburg, Russia 